UDC: $316.37: 321$

\title{
THE SOCIAL ESSENCE FOR LAW AND POLITICS
}

\author{
Radomir Stojanović \\ Associate professor, Faculty of Law, Kosovska Mitrovica University of Prishtina \\ radomir.stojanovic@pr.ac.rs
}

\begin{abstract}
The relationship of society, law and politics is extremely complex. The position of the individual in a necessary system of legal-political relations, we have subsumed under the original syntagm, t o t a $\mathrm{l}$ i z e d in d i v i d u a l it y, by which we denote the subordination of the individual to the regime of domination, which is in its turn, the expression of the interests of the ruling structures. Technological progress is the basis of this domination, whose base is the power to impose political and legal order, as a form of sociability that erases individuality. Technological development is far ahead of the organization of society, which is supposed to be following. We seek to structure the society in accordance with this fact in the idea of culture, which, by means of law and politics, is favoring the spirituality of the individual, as a dam for current superficial human existence. By means of culture, as the formula for structuring the society, human individuality should be preserved.
\end{abstract}

Keywords: society, law, antinomy, idea, culture, dimension, politics, aspect, ideology, imagination, reality, norm

\section{Introduction}

Society, law and politics are a manifestation of one sameness - man, but, at the same time, the contradiction of that very sameness. ${ }^{1}$ In his singularity (individuality), man fallows the principle of self-preservation and the instinct for individual preservation. His innate selfish gene (Dawkins) is forced to pair with the altruism instinct $^{2}$. In molecular, genetic structure, these instincts (impulses) are in the same relationship as individual and society are. That relationship is antinomic, resembling the one of magnetic poles (Spencer), because at one side, they are driven to the selfish pole, and at the other, to the sociable pole. The impossibility of survival of individuality forces it to connect to others. This interest for connecting has the same power as the self-preservation instinct. The characteristic of a society is to give the form of life need (interest) to human individuality and its sociable dimension.

\footnotetext{
${ }^{1}$ Compare: Adorno, Metakritik der Erkenntnistheorie, Frakfurt 1955.

2 Compare: Albert, Kritik der Reinen Erkenntislehre, Tubingen 1987
} 


\section{The concept of politics}

Man's vivid imagination invented and constructed law and politics to establish peace in "social menagerie". It can be distinguished between the "planning" of politics as a product of mind and political science as an artificially created notional structure of the so-called social contents. Politics itself is innate in human being. This is the part that distinguishes man from gods as well as from beasts (Aristotle). The political component of a society is made of man's individuality, as a politically sensitive being. To the extent of man being a logical and semantic being, i.e. meditative and communicative one, he is also a political person. The essence and mystery of politics are that man as an individual is forced by politics to cooperate with other people, although he intuitively does not do it for the benefit of society or other people, but for his own survival and existence. This makes basis for the possibility of transforming politics into the worst form of ideology. Under corrupted forms of political regimes, according to Aristotle, the utmost model of transformation of authenthic human politicalness into politics as the religion for ruling the masses.

\section{The concept of law}

Pure human imagination ${ }^{3}$ gave society its $1 \mathrm{a} w \mathrm{f} \mathrm{u}$ purpose. Law originated on the basis of $\mathrm{j} \mathrm{u} \mathrm{s} \mathrm{t} \mathrm{I} \mathrm{c} \mathrm{e} \mathrm{which} \mathrm{is,} \mathrm{in} \mathrm{turn,} \mathrm{that} \mathrm{instinct} \mathrm{or} \mathrm{intuition} \mathrm{born} \mathrm{together} \mathrm{with}$ a person and is most often recognized, comprehend or perceived through its negation i.e. injustice. ${ }^{4}$ The foundation of law coming into being is based on injustice. Law is the so-called $1 \mathrm{e}$ g a 1 justice which represents imaginary, man's mind projected for $\mathrm{m}$ of $\mathrm{n}$ e $\mathrm{g}$ a $\mathrm{t}$ e d justice. Law, actually, tends to shape the society, to bring order of imaginative constructions into its natural chaos. Law, as a so-called formally-logical group of law institutions embedded in laws and regulations, can be the most appropriate and also intellectually the most vulgar form, if it is an unrestrained expression of political voluntarism, expressed through sophistry and an apologia of autosuggestion of political morbidity In this way the law becomes the most powerful weapon of rulers, the subtlest and most complicated form which they use in order to maintain their own social positions of incommensurable megalomaniacal pretensions. Law gives to rulers, due to the so-called righteousness, the ability to indicate the fairness of their own political actions with full dignity of self-corruption. ${ }^{5}$ Politico-legal being of society in which politics and law are structured by the principles of individual human interest, sublime sense of individuality and human social meaning, in harmony of ethics and fairness, is shaped by one sublimated and synergetic overall notion. Many intellectuals failed to find the umbrella term. Social reality is so diffuse that it is very

3 Compare: Aristoteles, Metaphysics, London 1925.

4 Compare: Austin, The lecturer of Iurisprudence, Oxford 1863.

5 Compare: Austin, The Province of Iurisprudence Determined, Oxford 1832. 
difficult to find an idea that will shape it into a coherent order. It is possible ${ }^{6}$, if the law is perceived politically and politics explained by law. Political meaningfulness, and the appropriate rhetoric skills and imagination of real or imaginary illusion, is the most com mon form of the so-called political narrative, political speech in a high spiritual meaning, or pragmatic, real narrow meaning. In this way, politics does not speak of what is, but not only in principle, but also in conceptual-real senseof what needs to be. Political parties' programs are projections, visions, and usually intellectually sophisticated, but not profound, rather unfeasible construction of the so-called political mind. There too lies the sense of ideological attributes of politics and substantiality of its character and notion. Because of this, politics is beyond logic, and is often in extreme opposition to ethics, which is based on human dignity. In Plato's Idea, that the wise men should rule, the reason is in the coherent unity of kindness and understanding that they poses. The history of political spirit testifies just the opposite. Coincidences in the form of the realization of this idea only prove the rule of political mediocrity and the imbalance of ethics and wisdom. Politics is not "the art of possible". It would be more realistic to say that it is the art of achieving the impossible. Politics should harmonize the blind impulsiveness of human weakness, and pave the way for its realization by philanthropy and dignity.

\subsection{Law as a specific conceptual reality}

Law is, however, a specific conceptual reality. It belongs to the so-called third empire, to the logical being of reality, expressed and conveyed in legal institutions, which is a legal doctrine, but also contained in the legal norms, which is the law as a normative order, symbolically speaking, legislature. Law, as a normative order, although in its narrative form is about what ought to be, in its essence and content is about what is. In other words, what society is at the time of its legal structuring, is, at the same time, both what it is, and what it should be. The antinomy of a legal entity, viewed as a logical reality, is precisely in this relation about what i s and what $\mathrm{ex}$ i s $t$ s. Law is the reality of sociality diagnosed by formally-logical trial and ethical minimum. It is not a projection, but a diagnosis. Law is the for $\mathrm{m}$ of the a social reality and politics is, in principle (in an ideal sense), the c o n t e $\mathrm{n} t$ of a legal reality. The formally-legal structure of reality is built on the principles of perfect logical deduction. It goes from the general to the particular, and from the idea of the apriority of law it deduces the complete structure of complete legal and normative base. In this temple of logical spirit everything is so perfectly connected, and everything is coherently built up that it resembles a magnificent achievement of the so-called architectural spirit. The difference is in that the architectural mind goes from the specific to the general, i.e. from the foundation to the roof, and the law does the opposite. Law is the aspect of the s p i r it which, on the premises and postulates of social order, peace and security, builds the conceptual structure of legal order, peace

\footnotetext{
${ }^{6}$ Compare: Ayer, Language, Truth and logic, London 1936.
} 
and security. It is the order, which is the main, minimum and maximum requirement of functioning and survival of the socio-antagonistic impulses of selfishness. The law is the average, intellectual, legal and intellectual scope that allows human sustainability, for authentic cultural elevation and moral renaissance. In this way, the law shows what is and what should be in a society. Axiological character of law, reflected in fact, that through an invisible mission, it directs the society in advanced and, at the same time in backward sense The power of the legal mind, through logical stainlessness, exhibits the ability to imagine, through the diagnoses of the social i s, that what should be. In this regard, the language of law must be crystal clear, in Jering's words, and a lawyer must think like a philosopher and speak like a peasant ${ }^{7}$. Abstraction of the legal mind, contains not only the normativity of present social relation and reality, but also microscopically precise forecasting trends of social reality Law thus becomes an adviser of political spirit.

\section{The relation between law and politics}

Law and politics manifest their essential relationship in relationships of resources and goal. Politics uses law as a mere means of achieving goals, ascribing to itself authentic teleological mission. In principle, politics ought to be teleology, projections of goals and achievements of the same, according to the principles laid down in the programs of political parties. From the logical standpoint, law is a fundamental tool of politics, in order for the latter to achieve its goal. Law is the system of norms which politics uses for its own projection. In ideal and theoretical sense, law should be a tool of political ideology, because it has been equipped with the apparatus of primary power, as well as with sophisticated intellectuality and ethical minimum. However, the mind notices that politics delivers a murderous blow to its own supreme asset. Politics, according to the logic of its nature, the ideological and theological one, crashes structured legal order, followed by the essential content of social reality, at every stage of its architectural construction. The so-called legal security is the name for a relatively conservative and tenacious legal and normative order of society in a shorter or longer time interval. Politics as the strife for constant change, for designing of often imaginary and illusory goals, finds its crucial rival in the very law, which hampers its conceptual imagination. The thing that can connect politics and law is the idea that it may, at the same time, hold meaning and essence of the phenomenon of law and preserve the authentic spiritual form of political phenomenology. The most common and most controversial intellectual, and then general social conflicts come to being because politics wants to call into question the structured order of legality at any cost and by all means. Law resists with its intellectuality, spiritual strength and hidden teleology. However, from this conflict of irreconcilable, and more than senseless rivalry, the society loses most often. The responsibility lies on an unauthentic understanding

${ }^{7}$ Compare: Bergbohm, Iurisprudence, und Rechtsphilosophie, Leizig 1982. 
of the essence of the political spirit, and the nature of the legal intellect is the just and equitable resistance. Law is always in the function of social interdependence, and politics is aimed at achieving humanity and dignity, contrary to its authentic being. This contradiction stems from the fact that the apologists of the legal state and the rule of law cannot get rid of subjectivity, and formulate their own personality in functional terms, transforming it into superpersonal. It is essential to understand the difference between a personal psychological characteristic and an authentic legal and logical being of their objective mission and function. Throughout history, there were very few rulers who cleared up this distinction in their mind. The most common, the so-called political mind, cannot break away from its own passion, nor can it separate psychology from logic and perceive itself as a pure logical being. ${ }^{8}$ The society needs what can be called de-psychologisation of politics through those people who hold key positions in normative-legal order. The gap between glorification of the sense of legality and political subjectivism and voluntarism is a rule. By destroying objective properties, and staying within the horizon of passion, affinity and sensibility, politics by glorifying legality denies its own nature, destroying the fabric of selfhood, in terms of the fundamental means of political spirit. In order to understand the dynamic sense of the legal-political reality, as well as the static stratification of the overall pyramid of normative-legal terminology, one must proceed from the idea, which would be subjective a priori, comparable to Hans Kelsen's so-called Grundnorm, basic norm.

\section{The idea of culture}

Not feeling too bound by the usual canons of science, we start from the idea, which originally means for $\mathrm{m}$, by which ontological being of two forms of sociality, law and politics structure socio order by means of $\mathrm{cu} 1 \mathrm{t} u \mathrm{re}$ in all its aspects. The cultural aspect of the legal mission, is essential for achieving substantive meaningfulness of a society. Thus truly logical apriorism, allows the understanding of the objectives of the society from legal-normative order The idea of culture as intuitivity and awakened intellectuality is another name for the idea of the embodiment of a society in legal aspect. Without the idea of culture, law would be a hermetical control $\mathrm{m} \mathrm{e} \mathrm{ch}$ a $\mathrm{n}$ i s $\mathrm{m}$, which has granite logic, but without the influence on the creation of a society of human and dignifying nature. The spirit of the idea of $\mathrm{structuring}$ the society is achieved through law and politics, when politics is implemented by law. Political voluntarism is limited by competences stipulated by law. Difficulties arise, because the idea of structuring the society is in its essence at the level of spirituality above the intellectuality of political spirit. Its fullness of humanity, expressed through dignity, an individual and his forms of sociability (overall individuality), acquire solely by means of culture. This is the measure of every political projection, ideology and eschatology. From misunderstanding of the essential differences between civilization

${ }^{8}$ Compare: Berlin J, Emprical Propositions and Hypothetical statements, July 1950 
and culture, the political mind gives priority to civilization level of the spirit, which is manifested by the rule of the so-called techno logos, but the essence of culture lies in raising man's spiritual being. Politics was created as an expression and the reverse of diffuse sociability and the affirmation of "natural state", and authentic PlatonicAristotelian, its meaning. The idea of culture is the only authentic moral means to truly structure a society.

\section{Serbian Society}

Serbian society is being structured by means of law, photocopying, of the socalled European legal order, becoming a feeble-minded compilation of the overall contradictions of the so-called European law or the law of European Union. That is inappropriate and indecent to overall height of Serbian nation. It must be noted that our normative pseudo-spirituality has gone astray, imitating bad originals. When this is the situation in that part of society that is structured and symbolized by the legal form, then the things are as bad in politics. Serbian culture is getting lost in the fog of globalization. This kind of political mindlessness is acting by psychotronic directive, according to an ideological source that is directing it towards abyss and wilderness. Serbian identity ought to be developed from the idea of culture, and the same applies to its mental power and morality of St. Sava, which will free the society from the meaninglessness of totalitarianism imposed on it.

\section{I T E R A T U R E}

1. Adorno, Metakritik der Erkenntnistheorie, Frankfurt 1955

2. Albert, Kritik der reinen Erkenntnislehre, Tubingen 1987

3. Aristoteles, Metaphysics, London 1925

4. Arnds, Juristiche Enzyklopadie und Mathodologie, 1876

5. Austin, The lectures of Jurisprrudence, Oxford 1863

6. Austin, The province of Jurisprudence Determined, Oxford 1832

7. Ayer, Language, Truth and Logic, London 1936

8. Ayer, The Foundation of Empirical Knowledge, London 1947

9. Ayer, The Problem of Knowledge, London 1956

10. Ayer, Thinking and Meaning, London 1947

11. Bagolini, La scelta del metodo nella guirisprudenza, RTDPC, XI/1957

12. Bakker, Grundbegriffe des Rechts und Missgriffe der gesetzgebubg, 1910

13. Bergel, Methodes de droit, Theorie generale de droit, Paris 1985

14. Bergbohm, Jurisprudenz und Rechtsphilosophie, Leipzig 1982

15. Bergson, Creative Evolution, New York 1944

16. Bergson, L., Evolution Creatice, Paris 1919

17. Berlin I., Empirical Propositions and Hypothetical Statements, July 1950 
18. Berlin I., Two concepts of Liberty, London 1970

19. Binder, Philosophie des Rechts, 1925

20. Binder, Rechtsbegriff: Rechtsbegriff und Rechtsidee. Bemerkungen zur Rechtsphilosophie, Rudolf Stammler 1915

21. Blanshard B., Reason and Analysis, Yale 1961

22. Blanshard B., The nature of Thought, New York 1939

23. Bobbio, Teoria dela scienza guiridica, Torino 1950

24. Bolzano, Wisseschaftslehre, 1916

25. Brigman, Lte logic of Modern Phisics, New York 1927

26. Bund, Juristische Logik und Argumentation, Freiburg im Breisgau, 1983

27. Cairns, Legal Philosophy from Plato to Hegel, Baltimore, 1949

28. Carnap, Die logische Syntax der Sprache, Wien 1934

29. Carnap, Einfuhrung in die symbolische Logik, Wien 1954

30. Carnap, Introduction of Semantics, Cambridge, Massachusetts 1942

31. Carnap, Introduction of Semantics, Cambridge, Harward, University Press 1942

32. Cassirer, Kants Leben und Lehre, Berlin 1921

33. Cassier, Philosophie der symbolischen Formen, Bd. I-III, Berlin 1925

34. Cherry O., Human Communication, New York, 1957

35. Chomsky N., Knowledge of Language, New York - London 1986

36. Chomsky N., Language and Mind, New York 1965

37. Chomsky N., Reflections on Language, London 1976

38. Chomsky N., Syntactic Structures, Gravenhage 1957

39. Chomsky N., The Logical Structure of Linguistic Theory, London 1975

40. Darbellay, La regle juridique, St. Maurice 1945

41. Del Vecchio, Lezioni di filosofia del diritto, Milano 1958

42. Dewey, Experience and Nature, Chicaco - London 1926

43. Dewey, Logic, The theory of Inquiry, 1938

44. Donovan, The Festal, origin of Human Speech, "Mind" 1891-92

45. Drews, Einfuhrung in die Philosophie, 1921

46. Drews, Lebruch der Logik, 1928

47. Drews - Volkelt, Gewissheit und Wahrheit. Untersuchungen der Geltungsfrage der Erkenntnistheorie, 1918 